\title{
ANALISA PUTUSAN SENGKETA PILIHAN HUKUM WARIS
}

\author{
Oleh :
}

\author{
Bambang Yunarko
}

\begin{abstract}
In course of analysis and creation punish for case case which not yet there is its law order, judge is obliged to dig the law values which live and looked after its midst goodness is its society. Law values which live that for example: values of religion teaching, mores values which still be looked after a goodness, cultural and mount the society intellegence, social and economic circumstance of society.
\end{abstract}

Keyword : Case of Heir Case, Hereditary Law Order, Justice

\section{PENDAHULUAN}

Pemerintah Hindia Belanda, pada tanggal 30 April 1847 mengeluarkan Algemene Bepalingen van wetgeving voor Indonesia, (selanjutnya disebut A B) Staatsblad 1847 Nomor 23 yang sampai saat ini masih berlaku berdasarkan ketentuan Pasal II Aturan Peralihan Undang-Undang Dasar 1945 yang menyatakan, "Segala badan negara dan peraturan yang masih berlangsung berlaku selama belum diadakan yang baru menurut Undang-Undang Dasar ini".

Menurut pengertian pasal 22 A.B yang mengandung pengertian bahwa, "Hakim yang menolak untuk menyelesaikan suatu perkara dengan alasan bahwa peraturan perundang-undangan yang bersangkutan tidak menyebutkan, tidak jelas atau tidak lengkap, maka is dapat dituntut untuk dihukum karena menolak mengadili".

Dengan demikian, hakim mempunyai kewenangan untuk mencipta-kan hukum terutama terhadap kasus-kasus yang sama sekali belum ada hukumnya, tetapi telah masuk di Pengadilan.

Dalam proses analisa dan penciptaan hukum atas kasus-kasus perkara yang belum ada aturan hukumnya tersebut, hakim wajib menggali nilai-nilai hukum yang hidup dan dipelihara baik ditengah-tengahnya masyarakatnya. Nilainilai hukum yang hidup itu antara lain: nilainilai ajaran agama, nilai-nilai adat istiadat yang masih terpelihara baik, budaya dan tingkat kecerdasan masyarakat, keadaan 
sosial dan ekonomi masyarakat.

Hakim juga mempunyai kewenangan untuk menyimpangi ketentuan-ketentuan hukum tertulis yang telah ada yang telah usang ketinggalan zaman sehingga tidak lagi mampu memenuhi rasa keadilan masyarakat.

Hakim dalam menyimpangi aturan yang telah usang ini harus mencukupkan pertimbangan hukumnya secara jelas dan tajam dengan mempertimbangkan berbagai aspek kehidupan hukum.

Keputusan hakim yang berisikan suatu pertimbangan hukum sendiri berdasarkan kewenangan-kewenangan yang diberikan oleh Pasal 22 A.B yang kemudian menjadi dasar putusan hakim lainnya di kemudian hari untuk mengadili perkara yang memiliki unsur-unsur yang sama, dan selanjutnya putusan hakim tersebut menjadi sumber hukum di Pengadilan. Putusan hakim yang demikian itu disebut "Hukum Yurisprudensi".

Subekti, berpandangan lain dalam menilai sebuah hukum yurisprudensi, bahwa yang dimaksud dengan yurisprudensi adalah "Putusan-putusan Hakim atau Pengadilan yang telah berkekuatan hukum tetap dan dibenarkan oleh
Mahkamah Agung sebagai Pengadilan kasasi, atau putusan Mahkamah Agung sendiri yang sudah berkekuatan hukum tetap, maka barulah dapat dikatakan ada hukum yang dicipta melalui yurisprudensi". Jadi tidak semua putusan hakim tingkat pertama atau tingkat banding dapat dikatakan sebagai yurisprudensi, sebab untuk dapat dikategorikan sebagai yurisprudensi harus melalui proses "eksaminasi" dan "notasi" dari Mahkamah Agung dengan rekomendasi sebagai putusan yang telah memenuhi standar hukum yurisprudensi.

\section{RUMUSAN MASALAH}

Berdasarkan uraian tentang pengertian yurisprudensi tersebut diatas, maka dalam tulisan ini, dapatlah ditarik permasalahan yaitu : bagaimana putusan sengketa pilihan hukum waris dalam yuriprudensi.

\section{PUTUSAN MAHKAMAH AGUNG}

Nomor : 1615 K/Pdt/1993

DEMI KEADILAN BERDASARKAN KETUHANAN YANG MAHA ESA MAHKAMAH AGUNG memeriksa perkara perdata dalam tingkat kasasi telah mengambil putusan sebagai berikut dalam 
perkara :

NY. YASMIRAH, bertempat tinggal di Desa Laju Lor, Kecamatan Singgahan, Kabupaten Tuban, bertindak untuk diri sendiri dan juga sebagai wali dari anaknya yang belum dewasa bernama : KUSTIAWAN, dalam hal ini memberikan kuasa kepada Sugihartono, $\mathrm{SH}$ Pengacara/Konsultan hukum Pemohon kasasi (dahulu Tergugat Pembanding) melawan :

1. TARMIDJAH,

2. KUSMIYATI, keduanya bertempat tinggal di Desa Tanjungrejo, Kecamatan Singgahan, Kabupaten Tuba ;

3. KASPIYATI, bertempat tinggal di Desa Sendangharjo, Gang. 1 No 1 Tuban;

4. SUTARMAN, SH. bertempat tinggal di Jalan Setia Budi No. 16 Rembang Jawa Tengah, para Termohon kasasi (dahulu Penggugat Terbanding).

Mahkamah Agung tersebut :

Membaca surat-surat yang bersangkutan Menimbang, dst.

bahwa terhadap gugatan tersebut Tergugat telah mengajukan eksepsi yang pada pokoknya sebagai berikut : bahwa Pengadilan Negeri Tuban tidak berwenang untuk mengadili perkara ini, karena perkara ini adalah menyangkut :

1. Pembatalan Sertifikat Tanah Hak Milik yang dikeluarkan oleh Badan Pertanahan Nasional, dan dengan berlakunya Undang-Undang No. 5 tahun 1986 tentang Peradilan Tata Usaha Negara, maka perkara ini adalah merupakan kewenangan Pengadilan Tata Usaha Negara ;

2. Sengketa warisan antara para Penggugat konpensi dengan Tergugat konpensi, dst, bahwa memori kasasi dari Tergugat Pembanding tersebut telah diberitahukan kepada pihak lawan dengan seksama pada tanggal 10 Mei 1993;

Menimbang, bahwa permohonan kasasi a quo beserta alasanalasannya telah diberitahukan kepada pihak lawan dengan sekasama diajukan dalam tenggang waktu dan dengan cara yang ditentukan dalam Undang-Undang, maka oleh karena itu permohonan kasasi tersebut formal dapat diterima;

Menimbang, bahwa keberatankeberatan yang diajukan oleh pemohon kasasi dalam memori kasasinya tersebut pada pokoknya ialah: 
- Bahwa putusan Pengadilan Negeri yang dikuatkan oleh Pengadilan Tinggi telah me-langgar ketentuan pasal 134 HIR yaitu tentang kewenangan meng-adili karena berdasarkan Undang-Undang No.

7 Tahun 1989 dalam pasal (1) Undang-Undang No. 7 Tahun 1989, Pengadilan agamalah yang berwenang memeriksa, memutus dan menyelesaikan perkara ditingkat pertama antara orangorang yang beragama islam dibidang perkawinan, kewarisan, wasiat dan hibah yang dilakukan berdasarkan hukum islam juga tentang wakaf dan shadaqah, jadi bukan wewenang Pengadilan Negeri ;

Menimbang, bahwa keberatan ini dapat dibenarkan atas alasan sendiri sesuai dengan ketentuan pasal 52 Undang-Undang No. 14 Tahun 1985, Judex facti telah salah menerapkan hukum, karena telah menghilangkan sama sekali hak dan kedudukan para Tergugat asal untuk mewaris harta gonogini harta terperkara.

Sebagaimana yang disimpulkan oleh Judex facti, telah terbukti pakta- pakta berikut :

1. Tanah-tanah terperkara merupakan harta gono-gini antara Penggugat asal I dengan Kasdiman dalam kedudukan Penggugat asli I sebagai istri pertama.

2. Telah terbukti bahwa Kasdiman telah kawin dengan Tergugat asal I dalam kedudukan sebagai isteri kedua, dan Tergugat asal III anak yang sah dari Tergugat asal I dengan Kasdiman.

3. Telah terbukti Kasdiman sebagai suami Penggugat asal I dan Tergugat asal I telah meninggal dunia.

Berdasarkan fakta-fakta tersebut apa yang disengketakan sekarang menyangkut harta gono-gini antara almarhum Kasdiman dengan Penggugat asal I. Dengan demikian oleh karena Kasdiman telah meninggal dunia harta gono-gini tersebut harus dibagi dua. Ini berarti tanah-tanah terperkara harus dibagi dua dengan rincian sebagai berikut:

- $1 / 2$ bagian menjadi hak Penggugat asal I sebagai janda.

- $1 / 2$ bagian lagi jatuh menjadi bagian 
almarhum Kasdiman sebagai suami.

Ketentuan pembagian yang seperti ini sesuai dengan azas hukum yang dikembangkan dalam hukum adat dan analog dengan ketentuan pasal 37 Undang-Undang Nomor 1/1974 yakni dalam hal perkawinan pecah karena salah satu pihak meninggal dunia, harta gono-gini dibagi dua. Penerapan yang seperti ini sudah merupakan yurisprudensi tetap (stare decisis).

Berdasarkan landasan hukum diatas, 1/2 bagian yang menjadi hak Penggugat asal I secara mutlak jatuh menjadi haknya, dan hanya dapat diwarisi oleh anak-anak yang lahir dari Penggugat asal I. Sebaliknya mengenai 1/2 bagian yang menjadi hak Kasdiman menjadi budel warisan kepada seluruh ahli waris Kasdiman, dengan hak pembagian yang sama.

In casu, telah terbukti bahwa yang menjadi ahli waris Kasdiman adalah Penggugat asal I, II, III dan IV ditambah dengan Tergugat asal I dan Tergugat asal II. Dengan demikian, $1 / 2$ bagian yang menjadi hak Kasdiman, menjadi warisan Penggugat asal I, II, III dan IV bersamasama dengan Tergugat asal I dan II dan masing-masing mendapat $1 / 6$ bagian $\times 1 / 2$ dari harta-harta terperkara.

Berdasarkan pertimbangan diatas putusan Pengadilan Tinggi harus dibatalkan;

Menimbang, bahwa berdasarkan apa yang dipertimbangkan diatas, maka menurut pendapat Mahkamah Agung terdapat cukup alasan untuk mengabulkan permohonan kasasi dari Pemohon kasasi Ny. Yasmirah tersebut dengan membatalkan putusan Pengadilan Tinggi Surabaya tanggal 4 Maret 1993 Nomor 737/Pdt/1992/PT.Sby yang menguatkan putusan Pengadilan Negeri Tuban tanggal 13 Juni 1992 No. 03/Pdt.G/1991/PN.Tbn dan Mahkamah Agung akan mengadili sendiri perkara ini yang amarnya sebagaimana akan disebut dibawah ini ;

Menimbang, bahwa para Termohon kasasi/para Tergugat asal sebagai pihak yang dikalahkan dalam perkara ini, maka akan dihukum untuk membayar semua biaya perkara baik yang timbul dalam tingkat pertama dan tingkat banding maupun yang timbul dalam tingkat kasasi ;

Memperhatikan pasal-pasal dari Undang-Undang Nomor 14 Tahun 1970 dan Undang-Undang Nomor 14 Tahun 
1985 yang bersangkutan ;

MENGADILI

Mengabulkan permohonan kasasi

dari Pemohon kasasi NY.

YASMIRAH tersebut;

Membatalkan putusan Peng-

adilan Tinggi Surabaya tanggal 4 Maret 1993 No. 737/Pdt/1992/PT Sby yo putusan Pengadilan Tuban tanggal 13 Juni 1992 No. 03/Pdt.G/1992/PN.TBN, ;

DAN MENGADILI SENDIRI :

DALAM KONPENSI :

DALAM EKSEPSI :

- Menolak eksepsi dari Tergugat;

MENOLAK POKOK PERKARA:

- Mengabulkan gugatan Penggugat-

Penggugat untuk sebagian :

1. Menyatakan para Penggugat adalah ahli waris dari almarhum Kasdiman;

2. Menyatakan harta-harta terperkara gono-gini Penggugat I dengan Kasdiman;

3. Menyatakan Sertifikat Nomor 4 Tahun 1983 gambar situasi Nomor 759 Tahun 1983, nomor 5 Tahun 1983 gambar situasi No. 758 Tahun 1983 dan Nomor 6 Tahun 1983 gambar situasi Nomor 1006 Tahun 1983, tidak mempunyai kekuatan hukum;
4. Menolak gugatan PenggugatPenggugat selain dari selebihnya;

DALAM REKONPENSI :

- Mengabulkan gugatan Penggugat dalam rekonpensi untuk sebagian :

1. menyatakan tanah perkara gonogini Penggugat I dalam Konpensi/ Tergugat I dalam rekonpensi dengan Kasdiman, dan 1/2 bagian yang menjadi hak Kasdiman menjadi harta warisan dari semua ahli waris Kasdiman yang terdiri dari Penggugat I, II, III dan IV dalam konpensi/Tergugat I, II, III dan IV dalam rekonpensi serta Tergugat I dan II/dalam konpensi/ Penggugat I dan II dalam rekonpensi ;

2. menghukum para Penggugat konpensi/Tergugat dalam rekonpensi untuk menyerahkan $1 / 2$ bagian harta terperkara untuk dibagi waris antara para Penggugat dalam konpensi/para Tergugat dalam konpensi dengan para Tergugat dalam konpensi/ para Penggugat dalam rekonpensi masing-masing mendapat $1 / 6$ bagian ;

3. menolak selain dan selebihnya 
;Menghukum para Termohon kasasi/para Penggugat asal untuk membayar semua biaya perkara baik yang timbul dalam tingkat pertama dan dalam tingkat banding maupun dalam tingkat kasasi dan biaya dalam tingkat kasasi ini ditetapkan sebanyak Rp. 50.000,- (lima puluh ribu rupiah);

Demikianlah diputuskan dalam rapat permusyawaratan mahkamah Agung pada hari : Kamis, tanggal 20 April 1995 dengan M. YAHYA HARAHAP, SH. Hakim Agung yang ditunjuk oleh Ketua Mahkamah Agung sebagai Ketua Sidang, A. Saniman, SH dan Syafar Luthan, SH. sebagai Hakim-Hakim Anggota dan diucapkan dalam sidang terbuka untuk umum pada hari : SABTU, TANGGAL 29 APRIL 1995 oleh Ketua Sidang tersebut, dengan dihadiri oleh $\mathrm{S}$. saniman, $\mathrm{SH}$, dan H. Syafar Luthan, SH. Hakim-Hakim Anggota dan Djoko Soejatno, SH. Panitera Pengganti dengan tidak dihadiri oleh kedua belah pihak.

\section{Analisa Kasus Pilihan Hukum Waris}

Membahas hukum waris yang berlaku di Indonesia dalam dimensi keadilan, tidak dapat dihindari untuk pada akhirnya membandingkan antara hukum waris yang satu dengan hukum waris lainnya. Sebenamya eksistensi ketiga sistem hukum waris ini tidak menjadi masalah, asal setiap sistem hukum diberlakukan untuk subyek hukumnya masing-masing. Artinya masing-masing subyek hukum memilih satu sistem hukum untuk menyelesaikan masalahnya. Subyek hukum tidak dapat mencampuradukkan masing-masing sistem untuk menyelesaikan persoalan sesuai dengan kepentingan pribadinya. Misalnya, seseorang yang tunduk pada Agama Kristen, haruslah konsisten untuk tunduk pada sistem hukum BW. sedangkan subyek hukum yang beragama Islam tunduk pada sistem hukum Islam.

Analog dengan ketentuan Pasal 63 ayat 1 Undang-Undang Nomor 1 Tahun 1974 yang menentukan bahwa Pengadilan Agama bagi mereka yang beragama Islam, dan pengadilan umum bagi lainnya, maka dalam perkara warispun berlaku hal yang sama. Bagi warga masyarakat yang beragama Islam, berlakulah sistem hukum waris Islam. Bagi warga masyarakat yang bukan beragama Islam dapat diberlakukan sistem hukum waris adat atau sistem hukum waris (BW), yang di Indonesia 
sekarang hanya berlaku bagi warga negara keturunan Eropa dan keturunan China yang tidak beragama Islam.

Ketentuan hukum waris tidak dapat dipisahkan dengan hukum perkawinan. Paling tidak dapat dikemukakan dua alasan, yaitu pertama, penentuan ahli waris dimulai dari adanya perkawinan. Oleh karena itu janda atau duda adalah ahli waris, demikian juga hasil perkawinan berupa anak keturunan mereka adalah ahli waris. Kedua, penentuan harta waris didasarkan pada separuh harta bersama yang diperoleh selama perkawinan, ditambah dengan harta bawaan. Dalam hubungan dengan hal ini Pitlo menyata-kan bahwa hukum waris itu merupakan campuran antara bidang yang dinamakan hukum kekayaan dan hukum kekeluargaan.

Selama ini di masyarakat banyak persoalan pembagian waris diajukan kepada Pengadilan Negeri, tidak peduli apakah pada pihak yang bersengketa itu orang Islam atau non Islam. Padahal menurut hitungan jumlah umat Islam di Indonesia adalah terbesar, maka logika politisnya, jika persoalan waris bagi keluarga muslim diserahkan ke- wenangannya kepada Peradilan Negeri, maka akan merugikan umat Islam secara relegius, tetapi juga merugikan umat Islam secara politis.

Antisipasi terhadap kekhawatiran tersebut diatas harus dirintis oleh pakar hukum Islam yang memiliki kemampuan dan komitmen tinggi dalam upaya menciptakan sarana hukum yang dapat melahirkan keputusan hukum yang memiliki nurani iman dan keadilan abadi. Rintisan yang dimaksud telah dirumuskan pada beberapa pasal dalam kodifikasi/ kompilasi hukum waris atau keluarga, yang memerlukan dukungan dengan mengaktualisasikannya dalam yurisprudensi tetap yang diciptakan oleh para hakim di lingkungan Peradilan Agama.

Dalam kaidah ilmu hukum "ketentuan khusus harus dilakukan dari ketentuan yang bersifat umum". Secara yuridis formal patokan kewenangan mengadili bagi Peradilan Agama diatas secara khusus oleh Undang-Undang Nomor 7 Tahun 1989 Tentang Peradilan Agama, maka berdasarkan UndangUndang Nomor 7 Tahun 1989 inilah acuan kami untuk menganalisa, bahwa perkara pilihan hukum waris bagi orang islam 
adalah kewenangan absolut Peradilan Agama.

Kewenangan mengadili/ kekuasaan absolut peradilan agama telah diatur secara khusus pada Bab II pasal 49 Sangsi dengan pasal 53 Undang-Undang Nomor 7 Tahun 1989. Pasal 49 ayat (1) berbunyi :

Pengadilan Agama bertugas dan berwenang memeriksa memutus, dan menyelesaikan perkara-perkara di tngkat pertama antara orang-orang yang beragama Islam di bidang perkawinan, kewarisan, wasiat dan hibah yang dilakukan berdasarkan hukum wakaf dan shodaqoh.

Pasal 49 ayat (1) tersebut, telah secara jelas menyatakan, bahwa akidah Islam yang melekat pada jiwa pasal tersebut, maka menjadi patokan untuk menyelesaikan persoalan sengketa waris bagi orang Islam adalah dengan hukum Islam sebagai hukum yang hidup/hukum positif bagi orang Islam.

Sementara itu di kalangan umat Islam sendiri banyak mengira, bahwa sistem hukum kewarisan Islam tidak mencerminkan keadilan, dimana berdasarkan Al-Qur'an Surat Am-Nisaa ayat 11 , bagian warisan anak perempuan adalah separuh bagian warisan anak lakilaki. Demikian juga di dalam Kompilasi Hukum Islam pasal 176 antara lain di rumuskan, bagian anak laki-laki adalah dua berbanding satu dengan anak perempuan.

Kewenangan hukum Islam secara tekstual seperti diatas dapat menimbulkan ketidakadilan, maka upaya untuk menghadirkan keadilan adalah tidak hanya menerapkan syariat secara tekstual, namun perlu juga penerapan syariat secara kontekstual oleh para hakim di lingkungan peradilan agama dapat menampakkan pancaran keadilan.

Pada kasus yang menuntut keadilan, ketentuan syariat tersebut dapat ditafsirkan, bahwa bagian warisan anak perempuan minimal setengah bagian warisan anak laki-laki.

Walaupun Undang-Undang Nomor 7 Tahun 1989 Tentang Peradilan Agama telah memberikan kekuasaan secara absolut untuk menyelesaikan perkara waris bagi orang orang yang beragama Islam, namun masih banyak orang-orang Islam yang menghendak I penyelesaian perkara waris ke Pengadilan Negeri dikarenakan masih kurangnya tingkat kesadaran dan pemahaman hukum masyarakat utamanya 
para hakim sendiri pada pelaksanaan kewenangan absolut Pengadilan Agama dalam menyelesaikan perkara waris bagi orang Islam Hal tersebut diatas nampak dalam putusan Mahkamah Agung Nomor 1615 K/Pdt/1993 dalam perkara waris bagi orang-orang yang beragama Islam, dimana Mahkamah Agung seharusnya menolak perkara tersebut dengan pertimbangan hukum, bahwa perkara tersebut adalah menjadi wewenang Pengadilan Agama, seperti yang tertera pada eksepsi pihak tergugat, karena semua pihak yang berperkara tersebut beragama Islam, akan tetapi dalam perkara tersebut diatas Mahkamah Agung memeriksa dan memutus perkara baik yang sifatnya menguatkan atau memperbaiki putusan Pengadilan Negeri di Pengadilan Tinggi.

Demikian halnya apabila Mahkamah Agung Konsisten terhadap Surat Edaran Nomor 2 tahun 1990 tentang petunjuk pelaksanaan undangUndang Nomor 2 Tahun 1989, dimana bunyi Surat Edaran tersebut diantaranya berbunyi, bahwa Pengadilan Negeri masih diperkenankan memeriksa dan memutus perkara warisan bagi orang Islam sampai batas waktu 1 Juli 1990, akan tetapi perkara tersebut terdaftar di Pengadilan Negeri tahun 1992 dan tahun 1993, maka keberadaan beberapa yurisprudensi tersebut diatas menunjukkan tidak konsistennya Mahkamah Agung dalam memutus perkara waris bagi orangorang yang beragama Islam.

\section{PENUTUPAN}

Berdasarkan Yurisprudensi Mahkamah Agung Nomor : 1615 K/Pdt/1993 tentang waris, mahkamah agung belum konsisten terhadap kaidah hukum Lex Spesialis Derogat Lex Generalis dan Surat Edaran Mahkamah Agung Nomor: 2 Tahun 1990 karena masih memberikan kewenangan kepada Pengadilan Negeri untuk memeriksa dan memutus perkara waris bagi pihak-pihak yang beragama islam.

\section{DAFTAR PUSTAKA}

Abdullah, Siddik, Hukum Waris Islam dan Perkembangannya di seluruh Dunia Dalam, Wijaya, Jakarta, 1984.

Achmad Rustandi dan Muchjidin Efendi, Komentar Atas undang-Undang Nomor 7 Tahun 1989 Tentang Peradilan Agama, Unimus, Bandung, 1991. 
Afdol, Penerapan Hukum Waris Islam Secara Adil, Airlangga University Press, Surabaya, 2003.

Afdol, Landasan Hukum Positip Pemberiakuan Hukum Islam dan Permasalahan Implementasi Hukum Kewarisan Islam, Airlangga University Press, Surabaya, 2003.

Ahmad Kamil dan M. Fausan, KaidahKaidah Hukum Yurisprudensi, Kencana, Jakarta, 2004

AH. Daud, Hukum Islam Pengantar IImu Hukum dan Tata Hukum di Indonesia, Raja Grafindo Persada, Jakarta, 2001.

A. Rasyid, Raihan, Hukum Acara Peradilan Agama, Raja Grafindo Persada, Jakarta, 1996.

Budiono, A Rachmad, Pembahasan Hukum Kewarisan Islam di Indonesia, Citra Aditya Bhakti, Bandung, 1999

Djamali, Abdul, Hukum Islam Berdasarkan Ketentuan Kurikulum Konsorsium IImu Hukum, Mandar Maja, Bandung, 2002.

Harahap, Yahya, Kedudukan Kewenangan dan Acara Peradilan Agama, Pustaka Kartini, Jakarta, 1993.

Hadi Kusumo, Hilman, Hukum Waris Indonesia Menurut PemndangUndangan, Hukum Adat, Hukum Agama Hindu dan Islam, Aditya Bhakti, Bandung, 1991.
Hadi Kusumo, Hilman, Hukum Waris Adat, Aditya Bhakti, Bandung, 1993.

Otje Salamon dan Mustafa Haffas, Hukum Waris Islam, Rafika Aditama, Bandung, 2002.

Pitlo, A dalam Isa Marief, Hukum Waris Menurut Kitab Undang-Undang Hukum Perdata Belanda, Internusa, Jakarta, 1979.

Pohon, M. Hukum Waris, Djumadi, Surabaya, 1981.

Projodikoro, Wirjono, Hukum Warisan Indonesia, Sumur, Bandung, 1976.

Salim Oemar, Dasar-Dasar Hukum Waris di Indonesia, Rineka Cipta, Jakarta, 2000

Somardi, A Sukris, Transendeksi Keadilan Hukum Waris Islam Transformatif, Raja Grafindo Persada, Jakarta, 1997.

Soekanto, Soerjono, Pengantar Penelitian Hukum Universitas Indonesia Press, Jakarta, 1986.

Soepomo, Bab-Bab Tentang Hukum Adat, Pradnya Paramita, Jakarta, 1994. Subekti, Pokok-Pokok Hukum Perdata, Internusa, Jakarta, 1984.

Subekti dan Tjitro Sudibyo, Kitab UndangUndang Hukum Perdata, Pradnya Paramita, Jakarta, 1992.

Sukini Alham Syarif dan Nurul E, Hukum Kewarisan Perdata Barat, Fakultas Hukum UI, Jakarta, 2005.

Tamakiran S, Asas-Asas Hukum Menurut Tiga Sistem Hukum, Pionir Jaya, Bandung, 2004. 
Terhar, Asas-Asas Hukum Adat, Pradnya Paramita, Jakarta, 2001.

Wignyodipoero, Soepoyo, Pengantar Dan Asas-Asas Hukum Adat, Gunung Agung, Jakarta, 1995.

\section{PERATURAN PERUNDANGAN}

- Undang-Undang Dasar 1945 Amandemen IV

- Undang-Undang Nomor 4 Tahun 2004 Tentang Kekuasaan Kehakiman

- Undang-Undang Nomor 5 Tahun 2004 Tentang Perubahan Atas UndangUndang Nomor 14 Tahun 1985 Tentang Mahkamah Agung
- Undang-Undang Nomor 8 Tahun 2004 Tentang Perubahan Undang-Undang Nomor 2 Tahun 1986 Tentang Peradilan Umum

- Undang-Undang Nomor 31 Tahun 1997 Tentang Pengadilan Dan Oditur Dilingkungan Peradilan Mititer

- Undang-Undang Nomor 7 Tahun 1989 Tentang Peradilan Negara

- Undang-Undang Nomor 1 Tahun 1974 Tentang Perkawinan

- Undang-Undang Nomor 9 Tahun 2004 Tentang Perubahan Atas UndangUndang Nomor 5 Tahun 1986 Tentang Peradilan Tata Usaha Negara 